\title{
MAKNA "PERINTAH" SEBAGAI SALAH SATU UNSUR HUBUNGAN KERJA MENURUT UNDANG-UNDANG NOMOR 13 TAHUN 2003 TENTANG KETENAGAKERJAAN
}

\author{
Abdul Rachmad Budiono \\ Fakultas Hukum, Universitas Brawijaya \\ Email: Abdulrachmadbudiono@gmail.com
}

\begin{abstract}
:
One of the elements of employment relation is "command or work order". "Command or work order" as one of the employment relation elements is very important, but law and regulation do not regulate clearly. This paper based on normative legal research. Paper with statute approach and conceptual approach. The Legal issue in this paper is the meaning of "command or work order" as one of the employment relation element. "Command or work order" as one of the employment relation means verbal or writing statement of entrep-reneur, direct or indirect, to the labour, to do a work, with elements (1) the work order is an order to do a work, (2) the work order is in the area of employment relation, and (3) the work order is done with authority or competence.
\end{abstract}

Key words: work order, employment relation

\begin{abstract}
Abstrak
Salah satu unsur hubungan kerja adalah "perintah". "Perintah" sebagai salah satu elemen hubungan kerja amat penting, tetapi peraturan perundang-undangan tidak mengaturnya dengan jelas. Isu hukum di dalam penelitian ini adalah apa makna "perintah" sebagai salah satu unsur hubungan kerja. Tulisan ini berdasarkan penelitian hukum normatif. Pendekatan yang digunakan dalam penelitian ini adalah pendekatan undang-undang dan pendekatan konsep. Bahan hukum yang digali adalah bahan hukum primier dan bahan hukum sekunder. "Perintah"sebagai salah satu unsur hubungan kerja bermakna pernyataan lisan atau tulisan pengusaha, langsung atau tidak langsung, terhadap pekerja dengan unsur (1) perintah itu perintah untuk melakukan pekerjaan, (2) perintah itu ada di lingkup hubungan kerja, dan (3) perintah itu dilakukan dalam kekuasaan atau kewenangan.
\end{abstract}

Kata kunci: perintah, hubungan kerja

\section{Latar Belakang}

Tiga undang-undang di bidang perburuhan lahir setelah reformasi.Tiga undang-undang itu adalah (1) Undang-undang Nomor 21 Tahun 2000 tentang Serikat Pekerja/Serikat Buruh, (2) Undang-undang Nomor 13 Tahun 2003 tentang Ketengakerjaan, dan (3) Undang-undang Nomor 2 Tahun 2004 tentang Penyelesaian Perselisihan Hubungan Industrial. Meskipun ada sejumlah kekurangan pada undang-undang-undang-undang itu, dapat dikatakan bahwa tiga undang-undang tersebut merupakan perbaikan atas sejumlah undang-undang yang ada sebelumnya, misalnya (1) Undang-undang Nomor 22 Tahun 1957 tentang Penyelesaian Perselisihan Perburuhan, (2) Undang-undang Nomor 12 Tahun 1964 tentang Pemutusan Hubungan Kerja di Perusahaan Swasta, dan (3) Undang-undang Nomor 14 Tahun 1969 tentang Ketentuan-ketentuanPokokMengenaiTenagaKerja.

Salah satu perbaikan yang dibawa oleh Undang-undang Nomor 13 Tahun 2003 tentang Ketenagakerjaan (selanjutnya disingkat UK) adalah pengaturan mengenai hubungan kerja. Hubungan kerja merupakan hubungan hukuman- 
tara pengusaha dan pekerja/buruh. ${ }^{1}$ Pasal 1 angka 15 UK menegaskan, "Hubungan kerja adalah hubungan antara pengusaha dengan pekerja/buruh berdasarkan perjanjian kerja, yang mempunyai unsur pekerjaan, upah, dan perintah". Rumusan tentang hubungan kerja di dalam Bab I ini diikuti dengan Bab IX tentang Hubungan Kerja. Bab IX UK ini terdiri atas 17 pasal.Dengan demikian di dalam UK, khusus mengenai hubungan kerja, diatur di dalam 17 pasal (terdidi atas pasal 50 sampai dengan pasal 66) ditambah satu pasal, yaitu pasal 1 angka 15 .

Unsur hubungan kerja adalah (1) pekerjaan, (2) upah, dan (3) perintah. Hubungan hukum yang secara kumulatif berunsur pekerjaan, upah, dan perintah, merupakan hubungan kerja. Tiga hal ini merupakan unusr pembentuk agar hubungan hukum merupakan hubungan kerja. Merupakan hal yang amat penting untuk menentukan apakah hubungan hukum tertentu merupakan hubungan kerja atau bukan hubungan kerja. Dikatakan demikian sebab ada konsekuensi yang amat berbeda jika sesuatu diklasifikasikan hubungan kerja atau bukan hubungan kerja. Ada hubungan kerja berarti ada pekerja. Ada pekerja berarti ada perlindungan hukum oleh sejumlah peraturan perundang-undangan untuk pekerja, misalnya di bidang pengupahan, jaminan sosial tenaga kerja, waktu kerja, cuti, dan lain-lain.

Salah satu unsur pembentuk hubungan kerja adalah "perintah". Tidak ada kejelasan makna "perintah" sebagai unsur pebentuk hubungan kerja di dalam 18 pasal di dalam UK, termasuk di dalam penjelasan pasal-pasal tersebut. Akibat ketidakjelasan makna "perintah" sebagai unsur pembentuk hubungan kerja tersebut ada kesulitan untuk menentukan apakah hubungan hukum tertentu merupakan hubungan kerja atau bukan. Contohnya adalah hubungan hukum antara pembantu rumah tangga dengan orang yang mempekerjakannya. Sudah sejak lama para ahli memperdebatkan apakah hubungan hukum di antara mereka merupakan hubungan kerja atau bukan. Salah satu bukti ketidakjelasan makna "perintah" sebagai unsur pembentuk hubungan kerja dikaitkan dengan hubungan hukum antara pembantu rumah tangga dengan orang yang mempekerjakan21nya adalah munculnya desakan agar segera dibentuk undang-undang yang mengatur hubungan hukum antara pembantu rumah tangga dengan orang yang mempekerjakannya.

Di masa sebelum UK, sejumlah istilah digunakan untuk menunjuk makna "perintah". Istilahistilah itu misalnya "petunjuk" dan "pimpinan".

Di masa ini hubungan kerja terjadi terjadi setelah adanya perjanjian kerja antara buruh dan majikan, yaitu suatu perjanjian di mana pihak kesatu, buruh, mengikatkan diri untuk bekerja dengan menerima upah pada pihak lainnya, majikan, yang mengikatkan diri untuk mempekerjakan buruh dengan membayar upah. ${ }^{3}$ dalam melakukan pekerjaannya buruh berada di bawah pimpinan pihak majikan. ${ }^{4}$ Jika diamati sesungguhnya sebelum berlakunya UK pun, "perintah" atau istilah-istilah "petunjuk" atau "pimpinan" tidak menunjukkan kejelasan makna. Berdasarkan uraian tersebut penelitian hukum untuk mencari kejelasan makna "perintah" sebagai salah satu unsur hubungan kerja menurut Undang-undang Nomor 13 Tahun 2003 tentang Ketenagakerjaan.

\section{Pembahasan}

\section{a. Pengertian Perjanjian Kerja}

Perjanjian kerja adalah perjanjian antara buruh dengan pengusaha atau pemberi kerja yang memuat syarat-syarat kerja, hak, dan kewajiban para pihak (pasal 1 angka 14). Karena ada dua kemungkinan komposisi subjek hukum yang bertindak sebagai pihak di dalam perjanjian kerja, yaitu: (a) buruh dan pengusaha, dan (b) buruh dan pemberi kerja, maka logika hukumnya, juga ada perbedaan antara perjanjian kerja dengan pihak (a) buruh dan pengusaha, serta (b) buruh dan pemberi kerja. Analisis tentang perbedaan ini harus dikaitkan dengan pasal 50 yang menegaskan, bahwa hubungan kerja terjadi karena adanya perjanjian kerja antara pengusaha dan buruh. Hal yang dapat disimpulkan dari pasal ini adalah bahwa hubungan kerja hanya terjadi karena perjan-

1. Undang-Undang Nomor 21 Tahun 2000 tentang Serikat Pekerja/Serikat Buruh, Undang-Undang Nomor 13 Tahun 2003 tentang Ketenagakerjaan, dan Undang-Undang Nomor 2 Tahun 2004 tentang Penyesaian Perselisihan Hubungan Industrial, memadankan istilah "pekerja" dan istilah "buruh". Di dalam penelitian ini digunakan istilah pekerja, semata-mata dengan pertimbangan efisiensi.

2. Iman Soepomo, Hukum Perburuhan bidang Hubungan Kerja, Djambatan, Jakarta, 1983, hlm. 71.

3. Ibid., hlm. 1 .

4. Ibid. 
jian kerja antara buruh dan pengusaha. Secara $a$ contrario dapat disimpulkan bahwa perjanjian kerja yang dibuat oleh bukan buruh dan bukan pengusaha (dalam hal ini adalah pemberi kerja) tidak melahirkan hubungan kerja. Perjanjian kerja antara buruh dengan pemberi kerja melahirkan hubungan hukum, tetapi bukan hubungan kerja.

Undang-undang Nomor 13 Tahun 2003 membawa paradigma baru, di mana ada perjanjian kerja yang tidak melahirkan hubungan kerja. Arah yang hendak dibangun adalah perluasan perlindungan hukum kepada pihak-pihak tertentu yang melakukan pekerjaan untuk orang lain. Hal ini dapat dilihat dari ketentuan Bab VII tentang Perluasan Kesempatan Kerja, yang meliputi pasal 39 sampai dengan pasal 41, dan Bab VIII tentang Penggunaan Tenaga Kerja Asing, yang meliputi pasal 42 sampai dengan pasal 49. Kalau sebelum undang-undang ini, perlindungan oleh hukum perburuhan hanya terbatas pada buruh, tetapi setelah undang-undang ini lahir, perlindungan oleh hukum perburuhan diperluas. Subjek hukum yang hendak dilindungi tidak saja buruh, melainkan setiap orang yang dipekerjakan oleh orang lain. Hal ini pula yang menjadi alasan bidang hukum ini disebut hukum ketenagakerjaan. Saya tetap memilih menggunakan istilah hukum perburuhan, sebagaimana saya uraikan pada kata pengantar.

Pengertian perjanjian kerja juga terdapat di dalam pasal 1601 a BW, yaitu: "De arbeidsovereenkomst is de overeenkomst waarbij de eene partij, de arbeider, zich verbindt, in dienst van de andere partij, den werkgever, tegen loon gedurende zekeren tijd arbeid te verrichten" (Persetujuan perburuhan adalah persetujuan dengan mana pihak yang satu, buruh, mengikatkan dirinya untuk di bawah perintahnya pihak yang lain, si majikan, untuk sesuatu waktu tertentu, melakukan pekerjaan dengan menerima upah) ${ }^{5}$. Kini kita jumpai dua pengertian perjanjian kerja, yaitu di dalam Undang-undang Nomor 13 Tahun 2003 dan di dalam BW. Meskipun tidak secara tegas dinytakan tidak berlaku, berdasarkan asas lex posteriori derogat lex priori, pasal 1601 a BW harus dipandang tidak berlaku lagi. Pandangan ini amat konstruktif untuk pembangunan hukum, yang salah satu tujuannya adalah menciptakan kepastian hukum.

Perjanjian kerja melahirkan hubungan kerja. Sebagaimana telah diuraikan di dalam bagian terdahulu, hubungan kerja adalah hubungan antara pengusaha dengan buruh berdasarkan perjanjian kerja, yang mempunyai unsur pekerjaan, upah, dan perintah. Tiga unsur inilah yang membedakan antara hubungan kerja di satu sisi dengan hubungan hukum di sisi lainnya. Hubungan hukum yang dilekati tiga unsur ini merupakan hubungan kerja.

\section{a.1. Pekerjaan}

Jenis, ruang lingkup, dan keluasan pekerjaan amat beragam. Oleh karena itu bisa dimengerti kalau Undang-undang Nomor 13 Tahun 2003 tidak merinci makna pekerjaan. Politik hukum seperti ini dimaksudkan agar undang-undang tersebut dapat mengikuti perkembangan zaman. Pekerjaan merupakan sesuatu yang amat sentral jika membahas tentang hukum perburuhan. Undang-undang hanya menentukan jika perjanjian kerja disebut secara tertulis, maka harus dimuat (a) nama, alamat perusahaan, dan jenis usaha, (b) nama, jenis kelamin, umur, dan alamat pekerja/buruh, (c) jabatan atau jenis pekerjaan, (d) tempat pekerjaan, (e) besarnya upah dan cara pembayarannya, (f) syarat-syarat kerja yang memuat hak dan kewajiban pengusaha dan pekerja/buruh, (g) mulai dan jangka waktu berlakunya perjanjian kerja, (h) tempat dan tanggal perjanjian kerja dibuat, dan (i) tanda tangan para pihak dalam perjanjian kerja. Adanya syarat dalam huruf (f), yaitu tentang syarat-syarat kerja yang memuat hak dan kewajiban pengusaha dan buruh memperjelas sesuatu yang harus dilakukan atau dikerjakan oleh buruh. Sesuatu yang harus dikerjakan oleh buruh, berarti kewajiban buruh untuk kepentingan pengusaha, dalam arti sempit, sesuai dengan perjanjian kerja adalah pekerjaan. Tidak dirincinya atau dibatasinya pengertian pekerjaan di dalam Undang-undang Nomor 13 Tahun 2003, atau di dalam peraturan perundang-undangan lainnya, adalah sesuatu yang logis menurut legal reasoning atau penalaran hukum. Dikatakan demikian karena apabila diberikan pengertian atau batasan tertentu, justru akan mempersulit pelaksanaan dan pengembangan hukum perburuhan, khususnya yang berkaitan dengan perlindungan hukum untuk buruh. 
Di dalam Kamus Besar Bahasa Indonesia kata pekerjaan dipadankan dengan tugas kewajiban. ${ }^{6}$ Sementara itu kata ini diartikan sebagai barang apa yang dilakukan (diperbuat, dikerjakan, dan sebagainya). ${ }^{7}$ Jika makna ini yang diikuti, maka pekerjaan merupakan sesuatu yang dikerjakan yang merupakan tugas atau kewajiban. Makna ini tidak jauh berbeda dengan makna yang diberikan oleh Oxford Advanced Learner,s. Kamus ini memaknai job sebagai a particular piece of work; a task; a responsibility, duty or function. ${ }^{8}$ Makna atau batasan menurut kamus-kamus tersebut dapat digunakan sebagai pedoman, walaupun tidak mengikat secara hukum. Di dalam berbagai kasus, dengan menggunakan berbagai macam metode menemukan hukum, hakim atau penegak hukum lainnya akan dapat memberikan makna pada kata pekerjaan.

Sementara itu, ada beberapa pasal di dalam WvK yang menegaskan tentang pekerjaan. Pasal 341 ayat (1) WvK menegaskan :"De kapitein voert het schip" (Nahkoda atau kapten memimpin kapal). Pasal 346 menegaskan :"De kapitein is verplicht voor de dan boord zijnde goederen van een gedurende de reis overleden opvarende te zorgen en ten overstaan van twee der opvarenden daarvan een behoorlijke beschrijring te maken of te doen maken, welke door hem en door deze opvarenden wordt ondertekend" (Nahkoda diwajibkan merawat barang-barang seorang penumpang yang meninggal selama perjalanan, yang berada di kapal dan dari barang-barang itu harus dibuat atau disuruh membuatnya suatu daftar perincian di hadapan dua orang penumpang, daftar mana harus ditandatangani oleh nahkoda dan dua orang penumpang itu).

\section{a.2. Upah}

Menurut pasal 1 angka 30 Undang-undang Nomor 13 Tahun 2003 upah adalah hak pekerja/ buruh yang diterima dan dinyatakan dalam bentuk uang sebagai imbalan dari pengusaha atau pemberi kerja kepada pekerja/buruh yang ditetapkan dan dibayarkan menurut suatu perjanjian kerja, kesepakatan, atau peraturan perundang-undangan, termasuk tunjangan bagi pekerja/buruh dan keluarganya atas suatu pekerjaan dan/atau jasa yang telah atau akan dilakukan. Penerima upah adalah buruh. Pembayar upah ada dua kemungkinan, yaitu pengusaha atau pemberi kerja. Aturan hukum dibayarkannya upah adalah perjanjian kerja atau kesepakatan atau peraturan perundang-undangan. Mengenai perjanjian kerja dan peraturan perundang-undangan memang sudah semestinya. Upah dapat didasarkan pada perjanjian kerja, sepanjang ketentuan upah di dalam perjanjian kerja tersebut tidak bertentangan dengan peraturan perundangundangan. Jika ternyata ketentuan upah di dalam perjanjian kerja bertentangan dengan peraturan perundang-undangan, maka yang berlaku adalah ketentuan upah di dalam peraturan perundangundangan. Berikut ini adalah ilustrasinya. A, seorang penusaha, mempekerjakan $\mathrm{B}$ sebagai buruhnya. Di dalam perjanjian kerja ditentukan bahwa upah B adalah Rp. 450.000,- per bulan. A maupun B telah sepakat mengenai besarnya upah ini. Akan tetapi, peraturan perundang-undangan untuk daerah tempat A dan B berada upah minimumnya adalah Rp. 650.000 ,- per bulan. Jika ini yang terjadi, maka yang berlaku adalah besarnya upah menurut peraturan perundang-undangan, yaitu Rp. 650.000,-.

Berbeda dengan perjanjian kerja dan peraturan perundang-undangan sebagai dasar pembayaran upah adalah kesepakatan. Menurut peraturan perundang-undangan, termasuk Undang-undang Nomor 13 Tahun 2003, kesepakatan merupakan salah satu syarat sahnya perjanjian, termasuk perjanjian kerja (lihat pasal 52 ayat (1) huruf a). Oleh karena itu, jika yang dituju adalah perjanjian, maka penggunaan kata kesepakatan dalam pasal 1 angka 30 adalah tidak tepat. Jika dikaitkan dengan pasal 89 ayat (3) juncto pasal 91, maka dapat disimpulkan bahwa kata kesepakatan dalam pasal 1 angka 30 harus ditafsirkan sebagai perjanjian. Pasal 89 ayat (3) menegaskan bahwa upah minimum sebagaimana dimaksud ayat (1) ditetapkan oleh Gubernur dengan memperhatikan rekomendasi dari Dewan Pengupahan Provinsi dan/atau Bupati/Walikota. Pasal 91 ayat (1) menegaskan bahwa pengaturan pengupahan yang ditetapkan atas kesepakatan antara pengusaha dan pekerja/buruh atau serikat pekerja/serikat buruh

\footnotetext{
6. Pusat Bahasa Kementerian Pendidikan dan Kebudayaan Republik Indonesia, Kamus Besar Bahasa Indonesia, Departemen Pendidikan dan Kebudayaan dan Balai Pustaka, Jakarta, 1990, hlm. 428.

7. Ibid.

8. A S Hornby, Oxford Advanced Learner's Dictionary, Oxford University Press, London, 1995, hlm, 639.
} 
tidak boleh lebih rendah dari ketentuan pengupahan yang ditetapkan peraturan perundangundangan yang berlaku. Sementara itu ayat (2) menegaskan bahwa dalam hal kesepakatan sebagaimana dimaksud pada ayat (1) lebih rendah atau bertentangan dengan peraturan perundangundangan, kesepakatan tersebut batal demi hukum, dan pengusaha wajib membayar upah pekerja/ buruh menurut peraturan perundang-undangan yang berlaku. Berdasarkan pasal 89 ayat (3) yang menentukan upah minimum kabupaten atau kota adalah gubernur. Setelah gubernur menetapkan upah minimum kabupaten atau kota ada kemungkinan pengusaha dan/atau buruh (mungkin juga serikat buruh) tidak puas atas ketetapan tersebut. Menindaklanjuti ketidakpuasan tersebut, pengusaha dan buruh atau serikat buruh mengadakan perundingan. Arahnya sudah jelas, pengusaha akan berusaha mengurangi atau menurunkan besarnya upah, sedangkan buruh atau serikat buruh akan berusaha menambah atau menaikkan besarnya upah. Ada kemungkinan perundingan tersebut menghasilkan perjanjian. Menghasilkan perjanjian inilah yang di dalam masyarakat sering disebut sebagai menghasilkan kesepakatan. Sayangnya, pembentuk undang-undang secara lugas menggunakan kata kesepakatan tersebut di dalam pasal 1 angka 30 dan juga pasal 91 ayat (1) dan ayat (2). Perjanjian yang dihasilkan ini dapat merupakan perjanjian tersendiri antara pengusaha dengan buruh khusus mengenai upah, atau ditambahkan sebagai klausula tertentu di dalam perjanjian kerja. Apa pun alasannya, perjanjian mengenai upah tersebut, besarnya upah tidak boleh lebih rendah atau bertentangan dengan peraturan perundang-undangan. Jika ketentuan ini dilanggar, sanksinya adalah kebatalan (batal demi hukum).

Sekedar untuk perbandingan pasal 1 angka 5 Undang-undang Nomor 3 Tahun 1992 tentang Jaminan Sosial Tenaga Kerja menegaskan bahwa upah adalah penerimaan sebagai imbalan dari pengusaha kepada tenaga kerja untuk suatu pekerjaan yang telah atau akan dilakukan, dinyatakan atau dinilai dalam bentuk uang ditetapkan menurut suatu perjanjian atau peraturan perundang-undangan dan dibayarkan atas dasar suatu perjanjian kerja antara pengusaha dengan tenaga kerja, termasuk tunjangan, baik untuk tenaga kerja sendiri maupun keluarganya. Ada dua perbedaan jika pengertian upah dibandingkan antara Undang-undang Nomor 13 Tahun 2003 dengan Undang-undang Nomor 3 tahun 1992. Pertama, mengenai subjek pembayarnya atau pihak yang berkewajiban membayar upah. Undang-undang Nomor 13 Tahun 2003 menentukan ada dua kemungkinan, yaitu pengusaha atau pemberi kerja. Sementara itu, mengenai istilah subjek penerima upah Undang-undang Nomor 13 Tahun 2003 menggunakan istilah buruh atau pekerja. Sedangkan Undang-undang Nomor 3 tahun 1992 menggunakan istilah tenaga kerja. Sesuai dengan sistem hukum perburuhan yang hendak dibangun, terutama dengan lahirnya Undang-undang Nomor 13 Tahun 2003, pengertian upah menurut Undangundang Nomor 3 Tahun 1992 harus dipandang tidak berlaku lagi, sebab di dalam dua undangundang tersebut ada dua perbedaan pengertian upah yang membawa konsekuensi yang berbeda.

Hal-hal lebih lanjut mengenai upah akan dibahas di dalam sub tentang kewajiban pengusaha.

\section{a.3. Perintah}

Menurut Kamus Besar Bahasa Indonesia "perintah" adalah perkataan yang bermaksud menyuruh melakukan sesuatu. ${ }^{9}$

Baik Undang-undang Nomor 13 Tahun 2003 maupun peraturan perundang-undangan sebelumnya tidak memberikan batasan atau definisi mengenai perintah. Kejelasan makna "perintah" sebagai salah satu unsur hubungan kerja menurut Undang-undang Nomor 13 Tahun 2003 tentang Ketenagakerjaan akan dicari dan ditemukan lewat penelitian ini.

\section{b. Syarat Sah Perjanjian Kerja}

Perjanjian kerja sah apabila memenuhi persyaratan sebagai berikut. Hal ini diatur di dalam pasal 52 ayat (1)

a. kesepakatan kedua belah pihak;

b. kemampuan atau kecakapan melakukan perbuatan hukum;

c. adanya pekerjaan yang diperjanjikan; dan 
d. pekerjaan yang diperjanjikan tidak bertentangan dengan ketertiban umum, kesusilaan, dan peraturan perundang-undangan.

Di dalam kepustakaan, dua syarat pertama disebut syarat subjektif, sedangkan dua syarat terakhir disebut syarat objektif. Tidak terpenuhinya syarat subjektif berakibat dapat dibatalkannya perjanjian, sedangkan tidak terpenuhinya syarat objektif berakibat batal demi hukumnya perjanjian itu. Pasal 52 ayat (2) dan ayat (3) menegaskan hal ini. Di dalam kepustakaan hukum dikenal dua istilah, yaitu (1) nietigheid, dan (2) vernietigbaarheid. Kebatalan suatu nietigheid atau batal demi hukum tidak perlu perbuatan hukum tertentu, sedangkan kebatalan suatu nietigbaarheid atau dapat dibatalkan perlu perbuatan hukum tertentu. N.E. Algra menyebut nietigheid atau batal demi hukum ini dengan kebatalan mutlak. ${ }^{10}$

Ada hal yang perlu dibahas berkaitan dengan pasal 52 ayat (3). Pasal ini menegaskan bahwa perjanjian kerja yang dibuat oleh para pihak yang bertentangan dengan ketentuan sebagaimana dimaksud pada ayat (1) huruf $\mathrm{c}$ dan $\mathrm{d}$ batal demi hukum (cetak miring dari penulis). Pertanyaan yang diajukan adalah tentang sesuatu yang batal demi hukum, yaitu apakah perjanjian kerja atau klausulanya (bagian dari perjanjian) saja. Pertanyaan ini diajukan berdasarkan ilustrasi sebagai berikut. A, seorang pengusaha, membuat perjanjian kerja dengan $B$, seorang buruh. Salah satu klausula dalam perjanjian kerja tersebut adalah bahwa waktu kerja untuk buruh 12 jam sehari. Klausula ini bertentangan dengan pasal 77 ayat (2) juncto pasal 78 ayat (1) Undang-undang Nomor 13 Tahun 2003. Pasal 77 ayat (2) menegaskan bahwa waktu kerja meliputi: (a) 7 (tujuh) jam 1 (satu) hari dan 40 (empat puluh) jam 1 (satu) minggu untuk 6 (enam) hari kerja dalam 1 (satu) minggu, atau (b) 8 (delapan) jam 1 (satu) hari dan 40 (empat puluh) jam 1 (satu) minggu untuk 5 (lima) hari kerja dalam 1 (satu) minggu. Sedangkan pasal 78 ayat (1) huruf b menegaskan bahwa waktu kerja lembur hanya dapat dilakukan paling banyak 3 (tiga) jam dalam 1 (satu) hari dan 14 (empat belas) jam dalam 1 (satu) minggu. Berdasarkan dua pasal ini salah satu klausula perjanjian antara A, pengu- saha, dengan B, buruh, tersebut bertentangan dengan undang-undang. Menurut pasal 52 ayat (3) perjanjian tersebut batal demi hukum.

Sesuai dengan teori hukum, jika suatu perjanjian batal demi hukum, maka perjanjian tersebut tidak pernah ada. ${ }^{11}$ Hal ini juga sesuai dengan pasal 1335 BW. Pasal ini menegaskan: "eene overeenkomst zonder oorzaak, of uit eene valsche of ongeoorloofde oorzaak, aangegaan, is krachteloos" (suatu perjanjian tanpa sebab atau dibuat karena suatu sebab palsu atau terlarang, tidak mempunyai kekuatan). Jika tidak ada perjanjian, maka tidak ada akibat hukum apa pun. Dengan demikian, jika suatu perjanjian kerja batal demi hukum, maka juga tidak ada akibat hukum apa pun, termasuk tidak ada status pengusaha maupun buruh. Di samping itu, perjanjian kerja yang batal demi hukum itu tidak melahirkan hak apa pun, baik bagi pengusaha maupun buruh. Jika dikaitkan dengan asas hukum perburuhan, yaitu memberikan perlindungan kepada buruh, maka kebatalan yang demikian itu tidak tepat. Menurut saya jika ada klausula perjanjian kerja yang bertentangan dengan undang-undang (berarti kausa tidak halal), maka tidak secara otomatis perjanjian kerja tersebut batal. Jika kebatalan tersebut merugikan buruh, misalnya mengurangi hak-hak buruh, atau bahkan meniadakan hak-hak buruh, atau menambah beban kewajiban buruh, sedangkan pengurangan atau peniadaan hak-hak buruh atau penambahan beban buruh itu bertentangan dengan undang-undang, maka cukup klausula yang bertentangan dengan undang-undang itu saja yang batal. Hal ini lebih konstruktif menurut hukum daripada kebatalan perjanjian kerja.

\section{c. Sejarah Peraturan Hubungan Kerja}

Pada masa Pemerintahan Hindia Belanda penduduk Indonesia (saat itu disebut Hindia Belanda) dibagi menjadi tiga golongan, yaitu (1) golongan Eropa, (2) golongan Timur Asing, dan (3) golongan Pribumi (Bumi Putra). Untuk masing-masing golongan penduduk tersebut berlaku hukum perdata yang berlainan. Hukum yang berlaku untuk masing-masing golongan penduduk tersebut adalah sebagai berikut:

10. N.E. Algra, Kamus Istilah Hukum Fockema Andreae Belanda-Indonesia, Binacipta, Jakarta, 1983, hlm. 320.

11. Abdul Kadir Muhammad, Hukum Perikatan, Citra Aditya Bakti, Bandung, 1992, hlm. 96. 
1. Untuk golongan Eropa berlaku seluruh hukum perdata Barat;

2. Untuk golongan Timur Asing Tionghoa berlaku seluruh hukum perdata Barat; sedangkan untuk golongan Timur Asing bukan Tionghoa berlaku sebagian hukum perdata Barat;

3. Untuk golongan Pribumi berlaku hukum Adat.

Hal-hal yang diuraikan di atas didasarkan pada pasal 131 juncto pasal 163 Indische Staatsregeling. ${ }^{12}$

Hukum yang mengatur hubungan kerja tidak terlepas dari keadaan yang diuraikan di atas. Pada mulanya hubungan kerja untuk golongan Pribumi berlaku hukum adat atau kebiasaan, termasuk jika golongan Pribumi bekerja pada golongan Eropa (hubungan kerja antar golongan). Keadaan ini tidak menguntungkan para pengusaha yang pada umumnya golongan Eropa, sebab sewaktu-waktu buruh Pribumi tersebut dapat meninggalkan pekerjaannya. Karena keadaan ini pada tahun 1872 Pemerintah Hindia Belanda menerbitkan aturan yang menambahi Algemene Politie Strafreglement, sehingga buruh Pribumi yang meninggalkan pekerjaannya diancam dengan pidana, yaitu dengan pidana denda antara $\mathrm{Rp} 16$,- hingga Rp 25,- atau hukuman kerja paksa selama 7 hingga 12 hari.

Ancaman pidana (poenale sanctie) pada hubungan kerja tersebut dirasakan sangat tidak adil. Peraturan tersebut hanya menguntungkan salah satu pihak saja, yaitu pihak pengusaha, yang pada umumnya golongan Eropa. Karena mendapat kritikan dan desakan, akhirnya ancaman pidana tersebut dicabut dengan Staatsblad tahun 1879 nomor 203. Kemudian dengan Staatsblad tahun 1879 nomor 256 pasal 1601 lama hingga pasal 1603 lama KUH Perdata diberlakukan untuk golongan Pribumi. Dengan demikian, kalau semula ada ancaman pidana bagi buruh Pribumi yang meninggalkan pekerjaannya, maka setelah berlakunya KUH Perdata tersebut untuk perbuatan yang sama hanya dapat dikenakan sanksi perdata, yaitu berupa ganti kerugian dengan cara mengajukan gugatan perdata (civile actie).

Judul bagian V Bab VII lama KUH Perdata adalah: van Huur van dienstboden en werklieden (tentang penyewaan pembantu-pembantu rumah tangga dan pekerja-pekerja kasar). Selengkapnya pasal 1601 lama hingga pasal 1603 lama KUH Perdata menegaskan sebagai berikut:

Pasal 1601 lama:

"Orang hanya dapat mengikatkan tenaganya untuk suatu waktu atau untuk usaha tertentu". Pasal 1602 lama:

"Si tuan, jika diminta di bawah sumpah, dipercaya keterangannya:

- mengenai besarnya upah yang diperjanjikan;

- mengenai pembayaran upah tahun yang silam;

- mengenai jumlah uang muka salama tahun yang berjalan;

- mengenai lamanya waktu perjanjian persewaan".

Pasal 1603 lama:

1. "Pelayan dan tukang, jika mereka disewa untuk waktu tertentu, tidak boleh meninggalkan pekerjaan mereka tanpa alasan yang sah dan tidak boleh diusir dari pekerjaan mereka sebelum waktu lamanya perjanjian itu berakhir;

2. Namun si tuan berwenang mengusir mereka sewaktu-waktu tanpa mengajukan alasan, tetapi dalam hal demikian ia wajib disamping upah yang telah menjadi hak buruh, membayar sebagai ganti rugi upah selama enam minggu terhitung mulai mereka diusir dari pekerjaan mereka;

3. Jika persewaan itu diadakan untuk waktu kurang dari enam minggu atau akan berlangsung untuk waktu kurang dari enam minggu, mereka berhak atas upah penuh".

Ada beberapa hal yang perlu dicatat dari pasal-pasal tersebut, yaitu (1) buruh (dalam arti buruh kasar, yakni tukang dan pelayan) dianggap sebagai sesuatu yang dapat disewakan, yang berarti disamakan dengan benda, (2) ada perlakuan yang sangat diskriminatif, yakni keterangan si tuan (pengusaha) dalam suatu perselisihan hubungan industrial dianggap benar begitu saja, tanpa mendengarkan keterangan dari pihak buruh.

12. Menurut Utrecht, pembagian hukum sipil di Indonesia dalam beberapa golongan hukum itu tidak diadakan karena paal 163 IS, tetapi diadakan karena beberapa peraturan lain. Pasal tersebut hanya menyatakan siapakah yang tergolong dalam masing-masing golongan itu. Lihat Utrecht, Pengantar dalam Hukum Indonesia, Penerbitan dan Balai Buku Indonesia, Jakarta, 1953, hlm. 79. 
Meskipun ada hal-hal yang demikian itu, menurut Profesor Iman Soepomo, pasal-pasal tersebut dapat dilihat kemanfaatannya, yaitu bahwa sejak tahun 1879 terdapat kesatuan hukum di bidang hubungan kerja. ${ }^{13}$

Pada tahun 1926 dengan Staatsblad tahun 1926 nomor 335, 377, 458 dan 570, pasal 1601 lama hingga pasal 1603 lama diganti dengan pasal 1601 hingga pasal $1601 \mathrm{x}$, pasal 1602 hingga pasal 1602 z, pasal 1603 hingga pasal 1603 z (Bab VII A). Staatsblad tersebut mulai berlaku pada tanggal 1 Januari 1927, tetapi, pasal 1601 baru hingga pasal 1603 baru tersebut tidak diberlakukan untuk golongan bukan Eropa. Tegasnya, pasal-pasal tersebut hanya berlaku untuk golongan Eropa. Bab VII A tersebut berlaku untuk buruh golongan Pribumi hanya apabila buruh golongan Pribumi tersebut bekerja pada majikan golongan Eropa, dan melakukan pekerjaan yang biasanya dilakukan oleh buruh Eropa. Berlaku juga Bab VII A tersebut bagi golongan Pribumi apabila ia sebagai pengusaha dari buruh Eropa. ${ }^{14}$

Sebagai kesimpulan dapat dikatakan bahwa Bab VII A KUH Perdata berlaku untuk:

1. Semua buruh Eropa, baik buruh rendahan maupun buruh atasan, baik yang bekerja pada pengusaha Eropa maupun yang bekerja pada pengusaha Indonesia;

2. Buruh Indonesia atasan yang bekerja pada pengusaha Eropa dan NV (Naamloze Vennotschap) atau PT (perseroan Terbatas);

3. Semua pengusaha Eropa dan pengusaha Indonesia yang mempekerjakan buruh Eropa;

4. Semua pengusaha Eropa dan NV atau PT yang mempekerjakan buruh Indonesia atasan;

5. Buruh Indonesia atasan dan pengusaha Indonesia Perusahaan Perkebunan yang terikat oleh Peraturan Perburuhan di Perusahaan Perkebunan (Anvullende Plantersregeling). ${ }^{15}$

Hal-hal yang diuraikan di atas erat kaitannya dengan perluasan berlakunya hukum perdata Barat, yakni (1) menyatakan berlakunya hukum perdata Barat kepada golongan Pribumi dan Timur Asing, dan (2) membuka kesempatan kepada golongan Pribumi dan Asia Timur Asing untuk dengan sukarela tunduk kepada hukum perdata Barat. Hal yang disebutkan terakhir ini dapat berupa (a) tunduk dengan sukarela kepada seluruh hukum perdata Barat, (b) tunduk dengan sukarela kepada sebagian hukum perdata Barat, (c) tunduk kepada hukum perdata Barat mengenai suatu perbuatan hukum tertentu, dan (d) dianggap tunduk kepada hukum perdata Barat karena melakukan perbuatan hukum tertentu.

Sekarang, dengan berlakunya Undangundang Nomor 13 Tahun 2003, pengaturan mengenai hubungan kerja ada di dalam undangundang ini. Karena BW dan WvK tidak termasuk peraturan yang dinyatakan tidak berlaku, maka dua peraturan tersebut masih berlaku sepanjang sesuatu belum diatur dan tidak bertentangan dengan Undang-undang Nomor 13 Tahun 2003. Dalam hal-hal yang terbatas, Undang-undang Nomor 13 Tahun 2003 merupakan lex specialis derogat lex generalis terhadap $\mathrm{BW}$ dan $\mathrm{WvK}$.

\section{d. Bentuk Perjanjian Kerja}

Undang-undang Nomor 13 Tahun 2003 menegaskan bahwa perjanjian kerja dibuat secara tertulis atau lisan. Undang-undang memberikan kebebasan kepada para pihak untuk menentukan bentuk perjanjian yang dikehendakinya, tetapi sesungguhnya prinsip yang dianut adalah prinsip tertulis. Perjanjian kerja kerja dalam bentuk lisan dapat ditoleransi karena kondisi masyarakat yang beragam (lihat penjelasan pasal 51). Undangundang hanya menentukan bahwa (a) segala hal, dan/atau (b) segala biaya, yang diperlukan bagi pelaksanaan pembuatan perjanjian kerja dilaksanakan oleh dan menjadi tanggung jawab pengusaha.

Aturan tentang kebebasan bentuk perjanjian itu merupakan aturan umum. Pasal 51 ayat (2) menentukan bahwa perjanjian kerja yang dipersyaratkan secara tertulis dilaksanakan sesuai dengan peraturan perundang-undangan yang berlaku. Pasal ini memberikan kemungkinan bahwa untuk perjanjian kerja tertentu dapat disyaratkan bentuk tertulis. Perjanjian kerja yang dipersyaratkan dalam bentuk tertulis di antaranya adalah:

1. perjanjian kerja waktu tertentu (pasal 57 ayat 1);

2. antarkerja antardaerah;

3. antarkerja antarnegara;

4. perjanjian kerja laut.

13. Iman Soepomo (II), Hukum Perburuhan bidang Hubungan Kerja, Jambatan, Jakarta, 1983, hlm. 28-29.

14. Ibid., hlm. 29.

15. Ibid., hlm. 30 
Diwajibkannya bentuk tertulis untuk perjanjian kerja tertentu tersebut bertujuan utama memberikan perlindungan kepada buruh. Misalnya adalah yang ditegasakan di dalam pasal 399 ayat (1) WvK, yaitu "De arbeidsovereenkomst tusschen den reeder en een arbeider, die als kapitein of scheepsofficier zal optreden moet op straffe van nietigheid, schriftelijk worden aangegaan" (Perjanjian kerja antara pengusaha dan seorang buruh, atas ancaman batal, harus dibuat secara tertulis). Keharusan bentuk tertulis dengan anacaman kebatalan ini merupakan aturan khusus. Menurut pandangan saya aturan ini, berdasarkan asas lex specialis derogat lex generalis, masih tetap berlaku. Aturan khusus lainnya yang juga masih berlaku adalah Aanvullende Plantersregeling (Peraturan di Perusahaan Perburuhan). Di dalam peraturan yang mulai berlaku 17 Januari 1938 ini ditegaskan bahwa perjanjian kerja dengan buruh harus diadakan dalam bentuk tertulis (pasal 3 ayat 1 ). Sementara itu di dalam pasal 15 ayat (1) ditegasakan bahwa pelanggaran (berarti membuat perjanjian kerja tidak tertulis) atasa pasal 3 ayat (1) dipidana dengan pidana kurungan selamalamanya dua bulan atau denda sebanyak-banyaknya lima ratus rupiah.

Berdasarkan pasal 3 ayat (1) juncto pasal 15 ayat (1) tersebut, meskipun ada keharusan untuk membuat perjanjian kerja dalam bentuk tertulis, tetapi akte bukan merupakan unsur pembentuk.

Meskipun sama-sama ada keharusan bentuk tertentu untuk perjanjian kerja di laut dan perjanjian kerja di perusahaan perkebunan, yaitu bentuk tertulis, ada perbedaan konsekuensi di antara keduanya. Jika tidak dibuat dalam bentuk tertulis, perjanjian kerja di laut dianggap batal (berarti dianggap tidak ada), sementara itu, perjanjian kerja di perusahaan perkebunan tetap dianggap ada (dengan demikian berarti ada majikan dan buruh), hanya saja majikan diancam pidana.

Berbeda dengan inti yang hendak ditunjuk oleh dua peraturan tersebut di atas adalah hal yang diatur dalam Vrije Arbeidsregeling (Peraturan tentang Mempekerjakan Buruh), Staatsblad nomor 540 tahun 1911 yang mulai berlaku 30 Oktober 1911. Pasal 1 ayat (1) peraturan tersebut menegaskan bahwa majikan wajib mencatat dalam daftar menurut contoh yang ditetapkan oleh atau atas nama pemerintah, nama buruh yang bekerja padanya dengan menyebutkan permulaan dan berakhirnya perjanjian kerja upah yang telah disetujui dan pinjaman buruh. Kewajiban yang dibebankan kepada majikan untuk mencatat tersebut tidak termasuk bentuk perjanjian kerja, akan tetapi jika majikan tidak melaksanakannya, maka ia diancam pidana sebanyak-banyaknya $\mathrm{Rp}$ 100,00 (pasal 5).

Pembebanan kewajiban melakukan pencatatan mengenai beberapa hal tersebut dimaksudkan untuk kepentingan buruh, sebab dengan pencatatan tersebut segera dapat diketahui oleh pihak-pihak tertentu, termasuk pemerintah, apakah majikan melanggar peraturan perundang-undangan atau tidak.

Jika perjanjian kerja dibuat sacara tertulis, Pasal 54 ayat (1) mensyaratkan hal-hal minimal yang harus dicantumkan, yaitu:

a. nama, alamat perusahaan, dan jenis usaha;

b. nama, jenis kelamin, umur, dan alamat pekerja/buruh;

c. jabatan atau jenis pekerjaan;

d. tempat pekerjaan;

e. besarnya upah dan cara pembayarannya;

f. syarat-syarat kerja yang menurut hak dan kewajiban pengusaha dan pekerja/buruh.

g. mulai dan jangka waktu berlakunya perjanjian kerja;

h. tempat dan tanggal perjanjian kerja dibuat; dan

i. tanda tangan para pihak dalam perjanjian kerja.

Hal-hal yang ditegaskan di dalam huruf e dan $f$ tersebut tidak boleh bertentangan dengan peraturan perusahaan, perjanjian kerja bersama, dan peraturan perundang-undangan yang berlaku.

Sekedar untuk perbandingan, BW pun tidak mensyaratkan bentuk tertulis untuk perjanjian kerja. Hal ini ditegaskan di dalam pasal 1601 $\mathrm{d}$, yaitu: "Wanneer eene arbeidsovereenkomst schriftelijk wordt aangegaan, zijn de kosten der akte en andere bijkomende onkosten ten laste van der werkgever" (Apabila perjanjian kerja dibuat tertulis, maka biaya akte dan lain-lain biaya, ditanggung oleh pengusaha). Secara a contrario, karena ada frase "apabila perjanjian kerja dibuat tertulis, .....", maka undang-undang memperbolehkan perjanjian kerja dibuat tidak tertulis atau lisan.

\section{e. Makna "Perintah" sebagai Salah Satu Unsur Hubungan Kerja}

Perintah adalah salah satu elemen atau unsur hubungan kerja. Hal ini ditegaskan di dalam pasal 1 angka 15 UK. Sebagai salah satu elemen 
pembentuk hubungan kerja, makna "perintah" amat penting. Untuk menemukan makna "perintah"dilakukan penelusuran yang diuraikan berikut ini.

Di dalam Burgerlijk Wetboek (selanjutnya disingkat BW) juga ditemukan istilah "perintah"(terjemahan), yaitu di dalam pasal 1601 a. Pasal 1601 a BW menegaskan, "persetujuan perburuhan adalah persetujuan dengan mana pihak yang satu, si buruh, mengikatkan dirinya untuk di bawah perintahnhya pihak lain, si majikan, untuk sesuatu waktu tertentu, melakukan pekerjaan dengan menerima upah". Menurut BW "perintah" merupakan elemen persetujuan perburuhan atau perjanjian kerja. Di dalam BW pun tidak dijelaskan tentang makna "perintah". Namun demikian kata "perintah" di dalam BW lebih jelas daripada makna "perintah" di dalam pasal 1 angka 15 UK. Di dalam BW kata "perintah"merupakan bagian frase "di bawah perintah untuk melakukan pekerjaan". Dengan demikian menurut BW kata "perintah" harus ditautkan dengan dilakukannya pekerjaan. Dengan pendekatan komparasi makna "perintah"yang terkandung di dalam BW dapat ditarik semakna dengan makna "perintah" di dalam pasal 1 angka 15. Dengan demikian salah satu elemen makna kata "perintah" di dalam pasal 1 angka 15 adalah bahwa perintah harus ditautkan dengan dilakukannya pekerjaan.

Uraian di atas bisa dibenarkan dengan diperkuat ilustrasi berikut ini. Ada pekerja wanita. Pekerja wanita ini diterima sebagai analis kredit di salah satu dealer sepeda motor. Setiap jam 10 pagi pekerja wanita tersebut diperintah (disuruh) menjemput anak pengusaha (menjemput dari sekolah). Satu dua kali, perintah tersebut dilakukan oleh pekerja wanita tersebut. Merasa tidak nyaman, perintah tersebut diabaikan oleh pekerja wanita tersebut. Dalam perkara ini menjemput anak pengusaha tidak bertautan dengan melakukan pekerjaan dalam suatu hubungan kerja.
Di dalam Harrap's Essential English Dictionary ditegaskan bahwa command adalah "Someone in authority commands you to do something when they order you to do it". ${ }^{16}$ Menurut kamus Harrap's ini elemen yang harus ada di dalam "command" atau "perintah" adalah "in authority" atau dalam kekuasaan atau kewenangan. Elemen "dalam kekuasaan" ini amat penting berkaitan dengan melekatnya kewengan pada subjek hukum tertentu dan saat kekuasaan atau kewenangan itu dijalankan. Pemegang kekuasaan memerintah (pengusaha) memang dilekati kekuasaan, tetapi pemegang kekuasaan tidak dapat setiap saat memerintah. Seorang pekerja yang sedang beristirahat tidak bisa diperintah oleh pemegang kekuasaan memerintah. Beradanya kekuasaan dan saat kekuasaan memrintah dilaksanakan merupakan elemen penting perintah.

Ada asas bahwa setiap perbuatan pasti bermotif dan bertujuan. Perintah pengusaha terhadap pekerja harus bermotif. Artinya perintah itu harus mempunyai motif logis dan sesuai dengan tujuan dilakukannya pekerjaan itu. Contoh berikut ini benar-benar terjadi. Seorang direktur bank memerintahkan seluruh pekerjanya untuk menolak permohonan kredit yang diajukan etnis tertentu. Perintah ini tidak bermotif dan tidak sesuai dengan tujuan dilakukannya pekerjaan. Eelemen terakhir "perintah" adalah pernyataan lisan atau tulisan, langsung atau tidak langsung, subjek hukum tertentu (pengusaha) terhadap pekerja.

\section{Kesimpulan}

"Perintah" sebagai salah satu unsur hubungan kerja menurut Undang-undang Nomor 13 Tahun 2003 tentang Ketenagakerjaan bermakna pernyataan lisan atau tulisan, langsung atau tidak langsung, pengusaha terhadap pekerja dengan unsur (1) perintah itu perintah untuk melakukan pekerjaan, (2) perintah itu dalam lingkup hubungan kerja, dan (3) perintah itu dilakukan dalam kekuasaan atau kewenangan.

\section{DAFTAR PUSTAKA}

\section{Buku}

A S Hornby, 1995, Oxford Advanced Learner's

Dictionary, Oxford University Press, London.
Abdul Kadir Muhammad, 1992, Hukum Perikatan, Citra Aditya Bakti, Bandung.

16. Harrap's Essential English Dictionary, Chambers Harraps Published Ltd, Edinburgh, 1995, hlm. 184. 
Anomim, 1995, Harrap's Essential English Dictionary, Chambers Harraps Published Ltd, Edinburgh.

Iman Soepomo (II), 1983, Hukum Perburuhan bidang Hubungan Kerja, Jambatan, Jakarta.

Iman Soepomo, 1983, Hukum Perburuhan bidang Hubungan Kerja, Djambatan, Jakarta.

N.E. Algra, 1983, Kamus Istilah Hukum Fockema Andreae Belanda-Indonesia, Binacipta, Jakarta.

Pusat Bahasa Kementerian Pendidikan dan Kebudayaan Republik Indonesia, 1990, Kamus Besar Bahasa Indonesia, Departemen Pendidikan dan Kebudayaan dan Balai Pustaka, Jakarta.
Subekti dan Tjitrosudibio, 1970, Kitab Undangundang Hukum Perdata, Pradnya Paramita, Jakarta.

Utrecht, 1953, Pengantar dalam Hukum Indonesia, Penerbitan dan Balai Buku Indonesia, Jakarta.

\section{Peraturan Perundang-undangan}

Undang-Undang Nomor 13 Tahun 2003 tentang Ketenagakerjaan.

Undang-Undang Nomor 2 Tahun 2004 tentang Penyesaian Perselisihan Hubungan Industrial.

Undang-Undang Nomor 21 Tahun 2000 tentang Serikat Pekerja/Serikat Buruh. 